\title{
BLACK WORKERS' SATISFACTION WITH THEIR PAY
}

\author{
X.C. BIRKENBACH
}

R. VAN DER MERWE

\section{DEPARTMENT OF INDUSTRIAL AND ORGANISATIONAL PSYCHOLOGY UNIVERSITY OF PORT ELIZABETH}

\section{OPSOMMING}

Navorsing in Suid-Afrika toon dat finansiële vergoeding die belangrikste faktor in die swart werker se werklewe is. Weinig studies is egter tot dusver aangepak om veranderlikes te ondersoek wat verband hou met die loontevredenheid van swart werkers. Die huidige studie se bevindinge dui aan dat werkers wat tevrede met hul lone is in die algemeen jonger is, meer skoolopleiding het en minder finansiële afhanklikes het as ontevrede werkers. Verder skyn dit asof hulle hul lone as meer regverdigd beskou en ook loonstelsels beter verstaan as ontevrede werkers.

It is generally accepted that money holds a great deal of symbolic value for people in our westernised society. It can not only be used for satisfying physical needs such as food, clothing and shelter, but also to satisfy many of the so-called higher-order needs such as status, esteem and recognition.

With regard to the black worker in South Africa who is being socialised into the westernised way of life at a very rapid rate, the role of money assumes particular importance. It is not surprising that studies have shown that pay is the most valued outcome a black worker expects from his job (Verwey, 1968; Backer, 1973). However, it is surprising that very little research has been reported in the literature in connection with black workers' feelings towards and satisfaction with their pay. The implications of this statement are thought-provoking particularly when one considers the magnitude of wage expenditures incurred by organisations as well as the possible undesirable effects of pay dissatisfaction such as absenteeism, labour turnover, grievances and strikes (Lawler, 1971).

The paucity of research with regard to pay can largely be ascribed to a general lack of theoretical and empirical knowledge concerning the role of money in influencing human behaviour. However, the definitive work of Lawler (1971) in connection with pay satisfaction 
and employee motivation has contributed greatly to narrowing the gap between psychological theory and organisational pay practices.

Lawler (1971) bases his model of pay satisfaction on equity theory as developed by Adams (1965) and others (e.g. Homans, 1961; Patchen, 1961) as well as on discrepancy theory used by Porter (1961). It is hypothesised that pay satisfaction is determined by the discrepancy between a person's perception of the pay he thinks he should receive and what he actually receives. Satisfaction is said to result when these two factors are in agreement. When pay actually received is less than what the person thinks it should be (i.e. underpaid), dissatisfaction arises. On the other hand, if actual pay exceeds perceptions of what it should be (i.e. overpaid), feelings of guilt and discomfort arise.

A person's feelings of equity play a major role in shaping his beliefs of what his pay should be. For example, employees compare their job inputs (e.g. skill, education, performance) and job demands (e.g. responsibility, working conditions) with the pay they receive and the pay received by others. The higher their inputs and job demands are, the higher they will feel their pay should be.

In addition to these factors, Dyer and Theriault (1976) believe that pay satisfaction is influenced by employees' perceptions and understanding of the organisation's pay system such as pay criteria and performance assessments. Also, certain environmental factors such as cost of living and an employee's financial needs and family obligations could affect his satisfaction with his pay. The more important these factors appear to the person, the greater the amount of pay he will expect to receive.

The present study was embarked upon to investigate some of the assumptions of Lawler's (1971) model of pay satisfaction in combination with the modifications suggested by Dyer and Theriault (1976).

Owing to diverse cultural and educational experiences it could be expected that black workers' views of their pay could differ from those of other groups especially in terms of aspects such as cost of living and understanding of pay practices. Balanced against this, are other factors which could affect pay satisfaction such as poor wage history, and low job input factors resulting from working on menial tasks with few job demands other than physical factors. 


\section{Respondents}

Data were gathered by means of structured interviews from a sample of 114 black male hourly paid production workers drawn from four secondary industry companies in the Port Elizabeth-Uitenhage industrial area. All the respondents had at least six months service with their respective companies and were drawn more or less equally from low, intermediate and high wage levels. After meeting these criteria, respondents were chosen at random.

\section{The Questionnaire}

For the purpose of the study a questionnaire was developed in which a number of areas relating to pay satisfaction were covered. The following areas are related to the research reported here: " perceptions of inside and outside equity, understanding of wage increments, and understanding of wage deductions. Response categories to these items were of an openended nature.

Employee satisfaction with pay was determined by means of one final item to which responses were recorded on a five point scale ranging from very dissatisfied to very satisfied. It was expected that at the end of the interview, having explored a number of aspects of pay and pay practices, the employee's mind would be more sharply focused on matters relating to pay. As the previous questions were phrased neutrally, being mainly of an objective perceptual nature and not attitudinal, employees were not expected to develop negative or positive response sets. Earlier pilot studies with multiple satisfaction items had revealed very high inter-correlations among items and appeared to be contributing little more than would a single question (Birkenbach, 1978).

On the basis of employees' responses to the pay satisfaction item, they were categorised into two groups, namely satisfied and dissatisfied and were then contrasted on a number of variables. Responses obtained from satisfied and dissatisfied workers were analysed and recorded as percentages. Differences between the two groups were determined by comparing percentage responses obtained from each group. Significant differences were calculated by means of a nomograph devised by Lawshe and Baker (1950). This nomograph is used to calculate an omega value $(\omega)$ which, when substituted in the appropriate formula, gives tvalues which indicate the significance of the differences between percentages.

\footnotetext{
* For a full discussion of the development and content of the questionnaire, refer to Birkenbach and Van der Merwe (1979). 
Out of the total sample of 114 workers, 23 (20 percent) indicated that they were either very satisfied or satisfied with their pay. These constituted the satisfied groups. The remainder (80 percent) stated that they were either undecided, dissatisfied or very dissatisfied with their pay. These employees constituted the dissatisfied group.

\section{RESULTS AND DISCUSSION}

\section{Biographical factors}

Age

The mean age for satisfied workers was 34,3 years, compared with 37,4 years for dissatisfied workers $(\mathrm{p}<, 01)$.

Length of service did not appear to be an influencing factor in this finding as the median length of service for satisfied workers was 4,9 years, and 5 years for dissatisfied workers.

The finding supports the results from previous research conducted in this regard (e.g. Lawler, 1971), but does seem in contrast to the stereotype of the older black worker being more settled and satisfied in his job.

\section{Educational background}

The mean number of years of schooling for satisfied employees was 7,4 years, compared with 6,8 for dissatisfied workers $(\mathrm{p}<, 01)$. As education can be considered an input factor which the worker brings to his job and which should be rewarded, the finding that satisfied workers had more education than dissatisfied workers is unexpected and appears to be in contrast with previous findings (Klein and Mahrer, 1966).

\section{Number of dependents}

Table 1 illustrates the percentages of satisfied and dissatisfied workers with regard to number of persons who are financially dependent on them. It will be observed that satisfied workers had fewer persons who were financially dependent on them than dissatisfied workers. This finding supports Goodman's (1974) hypothesis that the greater the financial obligations to the family, the less the satisfaction with pay.

Considering the rate of inflation in the country, the wages earned by blacks, as well as their home circumstances, it is believed that this factor will be of particular significance in black 
workers' satisfaction with their pay. In many cases blacks have large families and, in addition, are frequently expected to support relatives who are unable to support themselves. Consequently, the demands made by the "extended family" can be seen as providing strong reasons for pay dissatisfaction.

\section{$\underline{\text { TABLE } 1}$}

PERCEPTIONS OF SATISFIED AND DISSATISFIED WORKERS WITH REFERENCE TO NUMBER OF DEPENDENTS

\begin{tabular}{|c|c|c|c|c|}
\hline $\begin{array}{c}\text { Number of } \\
\text { dependents }\end{array}$ & $\begin{array}{c}\% \\
\text { satisfied }\end{array}$ & $\begin{array}{c}\% \\
\text { dissatisfied }\end{array}$ & $\omega$ & $\begin{array}{c}\text { Level of } \\
\text { significance }\end{array}$ \\
\hline $0-3$ & 35 & 7 & 0,51 & 0,01 \\
$4-7$ & 56 & 70 & 0,20 & N.S. \\
8 and more & 9 & 23 & 0,28 & N.S. \\
\hline
\end{tabular}

\section{Perceptions of company pay system}

\section{Perceptions of outside equity}

Outside equity refers to employees' views on the pay they receive in comparison with wages earned by workers in other organisations. Table 2 gives the percentage responses obtained from interviewees with regard on their feelings of equity of their pay in comparison with the earnings of referent others outside the organisation.

Firstly, it will be noted that a far greater percentage of dissatisfied workers felt that other companies paid higher wages than their own company did. Secondly, a greater percentage of satisfied workers saw that the wages paid by other companies were in some cases higher and in some cases lower than those paid by their own organisation. This finding suggests that satisfied employees probably had a more realistic perception of labour market conditions than dissatisfied workers. However, it will also be noted that a fairly large percentage of satisfied employees did not know what other companies paid their workers. Seemingly, ignorance of outside pay rates had contributed to their satisfaction with their pay. 
TABLE 2

PERCENTAGE RESPONSES OF SATISFIED AND DISSATISFIED IIDRKERS REGARDING WAGES PAID BY OTHER COMPANIES

\begin{tabular}{|l|c|c|c|c|}
\hline Other companies pay & $\begin{array}{c}\% \\
\text { Satisfied }\end{array}$ & $\begin{array}{c}\% \\
\text { Dissatisfied }\end{array}$ & $\omega$ & $\begin{array}{c}\text { Level of } \\
\text { significance }\end{array}$ \\
\hline More & 13 & 70 & 0,88 & 0,01 \\
Less & 22 & 9 & 0,27 & N.S. \\
Same & 4 & 4 & 0,00 & N.S. \\
Some more, some less & 26 & 9 & 0,33 & 0,05 \\
Don't know & 35 & 8 & 0,50 & 0,01 \\
\hline
\end{tabular}

\section{Perceptions of internal equity}

These perceptions relate to persons' feelings of the fairness of their pay compared with what other workers within the organisation earn. Results in this connection were not as clearcut as was the case with outside equity. Significant differences between the groups were found in a few areas only, and the sizes of the differences were very small. Table 3 gives the results of workers' feelings why co-workers doing similar work earned higher wages than they did.

Table 3 shows that dissatisfied workers (albeit a very small percentage), to a larger extent than satisfied workers, perceived that certain "negative" factors were responsible for wage discrepancies among co-workers. Regarding the second factor, namely, others earned

\section{$\underline{\text { TABLE } 3}$}

PERCENTAGE RESPONSES OF SATISFIED AND DISSATISFIED WORKERS REGARDING WHY CO-WORKERS EARNED MORE WAGES

\begin{tabular}{|l|c|c|c|c|}
\hline \multicolumn{1}{|c|}{ Reason } & $\begin{array}{c}\% \\
\text { Satisfied }\end{array}$ & $\begin{array}{c}\% \\
\text { Dissatisfied }\end{array}$ & $\omega$ & $\begin{array}{c}\text { Level of } \\
\text { significance }\end{array}$ \\
\hline Foreman likes them & 0 & 7 & 0,38 & 0,05 \\
Because of race & 0 & 7 & 0,38 & 0,05 \\
\hline
\end{tabular}

more because of their race, it was found that this particularly referred to coloured workers. Black respondents believed that coloured workers in certain jobs did the same work as they did, but received higher wages purely because of their race.

A further difference between satisfied and dissatisfied workers emerged in connection with the wages earned by workers doing less complex jobs. Five percent of dissatisfied workers $(\omega=0,33, \mathrm{p}<, 5)$ indicated that workers doing less complex jobs earned the same 
wages as they did, while none of the satisfied workers had this feeling. Although the proportion of respondents was very small, it is nevertheless evident that the reason for dissatisfaction was a result of perceived inequity in the sense that persons with smaller job inputs were receiving equal outcomes.

\section{Understanding of wage deductions}

One significant difference between the two groups emerged here, namely between respondents who did not understand any of their wage deductions. Nine percent of satisfied workers did not understand any of their pay deductions, while thirty two percent of dissatisfied workers fell into this category

$(\omega=0,42 ; \mathrm{p}<, 05)$.

This finding is not unexpected. When amounts are deducted for unknown reasons, dissatisfaction becomes predictable. It would furthermore appear as if satisfied workers have a better understanding of their companies' pay systems.

\section{CONCLUSION}

The study was undertaken to gain insight into some of the determinants of black workers' satisfaction with their pay. Overall, from the results obtained, it appears that black workers who are satisfied with their pay are generally younger, more educated, and have fewer financial dependents than dissatisfied workers. In addition, they have better perceptions of the equity of their pay and a better understanding of their companies' pay systems.

In accounting for these findings, it would seem that age is the driving variable in these relationships, as the other factors are to a degree contingent on it. It can, for example, be argued that younger (i.e. satisfied) workers have fewer financial dependents, which would imply that they have more cash available for own use. It can furthermore be speculated that younger workers on the average have more education than their older counterparts. The latter assumption may account for a better understanding of organisational pay systems and external market conditions, which would lead to more favourable perceptions of pay equity. Taken together, these factors could potentially lead to greater satisfaction with pay.

It is important to point out that because of the exploratory nature of the study an indepth analysis of the data using multi-variate statistical procedures was not considered feasible. Consequently, the relationships between the independent variables and pay 
satisfaction reported here cannot be considered as determinants of pay satisfaction, as the effects of other possible causative variables had not been controlled. Indeed, some of the relationships may very well disappear if certain variables are partial led out.

Nevertheless, it is believed that a number of areas have been highlighted which could be pursued in further research. More specifically, these areas relate to feelings of internal and external pay equity and understanding of company pay systems. Although the results of the study with regard to perceptions of internal pay equity did not show striking differences between satisfied and dissatisfied workers, it can be anticipated that more refined measures would show greater discrimination between these groups.

\section{ABSTRACT}

Research in South Africa has shown that money is the most important outcome desired by black workers in the work situation. However, few studies have attempted to establish which variables are related to black workers' satisfaction with their pay. The findings of the present study suggest that workers who are satisfied are generally younger, more educated and have fewer financial dependents than dissatisfied workers. In addition, they see their pay as being more equitable, and have a better understanding of their companies' pay systems than dissatisfied workers.

\section{REFERENCES}

Adams, J.S. Inequity in social exchange. In Berkowitz, L. (Ed.), Advances in Experimental and Social Psychology. (Vol. 2). New York: Academic, 1965.

Backer, W. Motivating Black Workers. Johannesburg: McGraw Hill, 1973.

Birkenbach, X.C. Employee Perceptions of Organizational Remuneration Systems: A Comparative Study of Black Employees in Four Secondary Industry Companies. Unpublished Masters Dissertation, University of Port Elizabeth, 1978.

Birkenbach, X.C. \& van der Merwe, R. Black employees perceptions of organizational pay practices: the development and application of an instrument. Psychologia Africana. 1979, 18(1). In press.

Dyer, L. \& Theriault, R. The determinants of pay satisfaction. Journal of Applied Psychology. 1976, 61, 596-604.

Goodman, P.S. An examination of referents used in the evaluation of pay. Organizational Behavior and Human Performance, 1974, 12, 170-195.

Homans, G.C. Social Behavior: Its Elementary Form. New York: Harcourt Brace, 1961.

Klein, S.M. \& Mahrer, J.R. Education level and satisfaction with pay. Personnel Psychology, 1966, 19, 195-208.

Lawler, E.E. Pay and Organizational Effectiveness: A Psychological View. New York: McGraw-Hill, 1971. 
Lawshe, C.H. \& Baker, P.C. Three aids in the evaluation of the significance of differences between percentages. Educational and Psychological Measurement, 1950, 10, 263-270.

Patchen, N. The Choice of Wage Comparisons. Englewood Cliffs: Prentice Hall, 1961.

Porter, L.W. A study of perceived need satisfactions in bottom and middle management jobs. Journal of Applied Psychology, 1961, 45, 1-10.

Verwey. F.A. The Attitudes, Job Expectations and Motivation of Bantu Employees in Industry. NIPR Report Pers, 165, 1968. 